\title{
Second report on the occurrence of Camponotus truncatus (Spinola) (Hymenoptera: Formicidae) in Poland, with a key to the Polish species of the genus Camponotus Mayr
}

\author{
Hanna SuCHOCKA*, Wojciech CzECHOWSKI** and Alexander RADCHENKO** \\ *Warsaw University of Live Sciences (SGGW), Faculty of Agriculture and Biology, Nowoursynowska St 159, \\ 02-776 Warszawa, Poland; e-mail: hsuchocka@gmail.com \\ **Museum and Institute of Zoology PAS, Laboratory of Social and Myrmecophilous Insects, Wilcza St 64, \\ 00-679 Warszawa, Poland; e-mails: wcz@miiz.waw.pl, agradchenko@hotmail.com
}

\begin{abstract}
A second locality of Camponotus (Colobopsis) truncatus (Spinola), a Mediterranean dendrobiotic ant species rare in Central Europe is reported from Poland. Single workers were collected from trunks of old oaks (Quercus robur L.) in the Rogalin Oak Wood within the Rogalin Landscape Park (Wielkopolsko-Kujawska Lowland, Western Poland). At the same time, besides C. truncatus, one more rare ant species, Temnothorax corticalis (Schenck), is reported from the Wielkopolsko-Kujawska Lowland for the first time. A key to workers of the Polish species of the genus Camponotus Mayr is given.
\end{abstract}

Key words: ants, Camponotus truncatus, Temnothorax corticalis, dendrobionts, oak forests, fauna of Poland

\section{INTRODUCTION}

Until recently, five species of the genus Camponotus Mayr, representing two subgenera, were known from Poland: Camponotus (Camponotus) herculeanus (L.), C. (C.) ligniperda (Latr.), C. (C.) vagus (Scop.), C. (Myrmentoma) fallax (Nyl.), and C. (M.) piceus (Leach). Two other previously reported species, $C$. (M.) lateralis (Olivier) and $C$. (Tanaemyrmex) aethiops (Latr.), have been crossed off the list of Polish myrmecofauna because of incredibility of the reports, based most probably on misidentifications (Czechowski et al. 2002; for the Polish species of Camponotus see also Pisarski 1961 and Krzysztofiak 1991). One more Camponotus species, C. truncatus (Spinola), a member of the subgenus Colobobsis Mayr, was found in Poland very recently (Borowiec 2007).

The subgenus Colobopsis includes about 115 species identified to date, distributed mainly in tropical and subtropical regions of India, South-Eastern Asia, Australasia and Central America. C. truncatus, a Mediterranean zoogeographical element, is the only representative of this subgenus which occurs in Europe (see Radchenko 1996, 1997, 2007). The European part of its compact range includes Southern and partly Central Europe, reaching a latitude of $50.4^{\circ}$ north; single scattered sites of $C$. truncatus reach farther, in Germany to the latitude of Berlin (i.e. to around $\left(52.3^{\circ} \mathrm{N}\right)($ Seifert 2007$)$. The present paper reports the second finding of this species in Poland

\section{OUTLINE OF BIOLOGY OF C. TRUNCATUS}

C. truncatus is a thermo- and hemixerophilous species, an oligotope of warm, light and dry deciduous forests, encountered also in mixed forests, old parks and orchards. It prefers sparse woods, mainly oak and juniper. As a typical dendrobiont it nests in dead parts (mainly dry 
branches) of living trees. Incipient colonies can also dwell in woody hollow stems of certain plants. Colonies are monogynous, numbering up to 500 workers. In mature colonies, the worker caste is strictly dimorphic (as in all members of the subgenus Colobopsis). Apart from ordinary (3-5 $\mathrm{mm}$ in length) workers, a number of soldiers (5-6 $\mathrm{mm}$ in length) are also seen; no intermediate morphs are present. A distinctive feature of soldiers is their strongly sclerotised plug-shaped anterior part of head, used by them to plug nest holes (see 'phragmosis' e.g. in Hölldobler \& Wilson 1990). The same head structure is characteristic of C. truncatus queens, in which it serves to close the nest entrance during the claustral period. Ordinary workers forage in tree canopies feeding on honey dew and preying on small insects. They very seldom walk down tree trunks, which makes the species hard to record. Soldiers do not leave the nests (Stitz 1939, Bernard 1967, Atanasov \& Dlusskij 1992, Seifert 2007). Most probably, soldiers of $C$. truncatus, besides their defensive role, serve also as a trophic subcaste in the colony, which is connected with their proportionately larger gasters. As has been found in C. fraxinicola M. R. Smith, a North-American member of the subgenus Colobopsis, the soldiers store large amounts of liquid food in their crops and their gasters are filled with large fat bodies (Wilson 1974).

\section{TRUNCATUS IN POLAND}

The first Polish record of C. truncatus was in an old urban park in Wroclaw $\left(51^{\circ} 12^{\prime} \mathrm{N}, 16^{\circ}\right.$ 59 'E; Lower Silesia) in 2006 (for more details see Borowiec 2007). The second finding, reported here, was at Rogalin (52 $14^{\prime} \mathrm{N}, 1^{\circ} 56^{\prime} \mathrm{E}$; UTM XT 38) near Poznań (WielkopolskoKujawska Lowland, Western Poland), about $120 \mathrm{~km}$ north of the former site (Fig. 1).

The Rogalin Oak Wood (Dęby Rogalinskie or Dąbrowa Rogalińska), the biggest cluster of old oaks in Europe, stretches out on the flooded terrace of the Warta river valley, within the Rogalin Landscape Park. The wood, consisting of about 2000 oaks, mainly Quercus robur L., several hundred years old, is a remnant of old ash-elm carrs of the association FicarioUlmetum (=Fraxineto-Ulmetum), in which $Q$. robur is a constant component of the tree stand

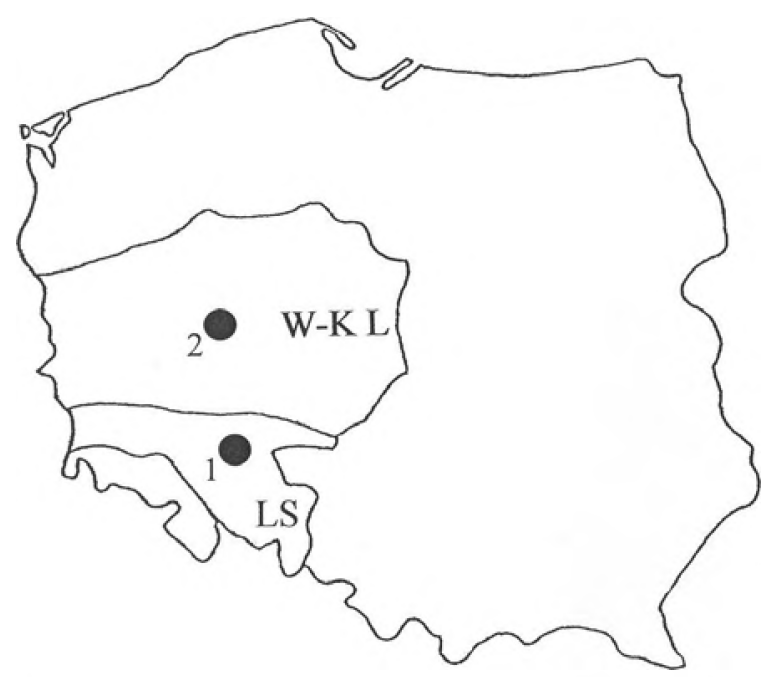

Fig. 1. Localities of C. truncatus in Poland: 1 - Wroclaw (after Borowiec 2007), 2 - Rogalin ad Poznań (new locality) (W-KL - Wielkopolsko-Kujawska Lowland, LS - Lower Silesia). 
(see Matuszkiewicz 1981). The edge of the oak wood is within the palace park at Rogalin, where it constitutes an English-style part of the park. Among other ants, two workers of C. truncatus were collected there from the oak trunks by the first author on $4^{\text {th }}$ and $5^{\text {th }} \mathrm{July}$, 2007. These specimens were found on different distant trees, possibly indicating (based on the biology of the species; see above) that they represented two separate colonies.

\section{OTHER RESULTS}

Besides C. truncatus, eight more ant species were recorded on the Rogalin oaks: Dolichoderus quadripunctatus (L.), Temnothorax corticalis (Schenck), Camponotus fallax (Nyl.), Lasius platythorax Seifert, L. brunneus (Latr.), Lasius fuliginosus (Latr.), Myrmica ruginodis Nyl., and Formica cunicularia Latr. The first six species are dendrobionts, so their presence on the old trees was not accidental. The most interesting of them is T. corticalis, which was recorded from the Wielkopolsko-Kujawska Lowland for the first time. It is a little known EuroCaucasian species, very rare in Poland and found only in xerothermal sites, an oligotope of light and dry deciduous forests, nesting in dead tree branches (mainly oak), in bark crevices and in dry fallen wood (see Czechowski et al. 2002). Another dendrobiont, C. fallax, was recorded from the Wielkopolsko-Kujawska Lowland for the second time (formerly it was reported exactly from the Rogalin Oak Wood; Banaszak 1977).

\section{DISCUSSION}

Although the ants of Poland are rather well known (Czechowski et al. 2002), species new for the country are still occasionally recorded (e.g. Radchenko et al. 2003, 2004, 2005). Recently (Borowiec 2007 and the present report), C. truncatus is an addition to the list of the Polish myrmecofauna. It should be mentioned here that there is one more, unpublished (based on a personal communication), recent report of the species under discussion reputedly found in Western Poland - halfway between the two "official" sites, but it requires confirmation. This series of recent finds is puzzling, especially in the context of a long tradition of faunistic myrmecological research in the western regions of Poland. The question arises whether $C$. truncatus has started to extend its range in Central Europe in recent years. It is possible the more so because C. truncatus was not found on the Rogalin oaks when the occurrence of hymenopterans was studied there in the mid-1970's (Banaszak 1977). On the other hand, those results are not too reliable as regards ants since only five ant species were recorded then, including only two dendrobionts ( $C$. fallax and Lasius fuliginosus), during a two-year fairly systematic investigation, i.e. fewer than recently collected by one person over two days.

\section{KEY TO THE POLISH SPECIES OF THE GENUS CAMPONOTUS (WORKERS) (after Czechowski et al. 2002, supplemented)}

1. Head of soldiers (and queens) sharply truncated anteriorly, lower part of frons and clypeus forming flat rounded plate (Fig. 2). Head of workers rounded, not truncated, and propodeal dorsum distinctly concave transversally (seen in profile) (Fig. 3). Head and alitrunk reddish, gaster brownish black C. truncatus (Spinola)

- Head of soldiers and queens not truncated anteriorly, propodeum of workers has another shape (Figs 4-9). Body colour various

2. Alitrunk in profile with distinct, often deep, metanotal groove, dorsal surface of propodeum flattened and meets its declivity at an acute or right angle (Fig. 4) ......... C. piceus (Leach)

- Alitrunk in profile gradually convex, without metanotal groove, its dorsum not flattened, forming more or less regular arch (Figs 8,9$)$ 
3. Anterior clypeal margin distinctly notched medially (Fig. 5) C. fallax (Nyl.)

- Anterior clypeal margin not notched medially (Figs 6, 7) 3

4. (3) Whole body black; occipital margin of head with numerous standing hairs (Fig. 6) C. vagus (Scop.)

- Alitrunk from yellowish red to brownish red, head and gaster brownish black; occipital margin of head without or, at most, with a few standing hairs (Fig. 7) 5

5. (4) At least basal third of first gastral tergite reddish, remainder of gaster brownish black (Fig. 8)

C. ligniperda (Latr.)

- At most declivity of first gastral tergite could be reddish, remainder of gaster brownish black (Fig. 9)

C. herculeanus (L.)

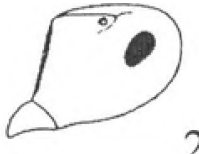

2

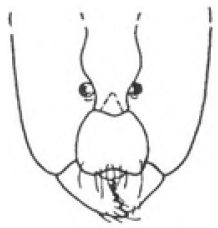

5

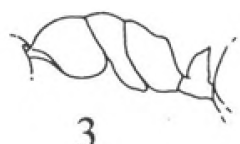

3

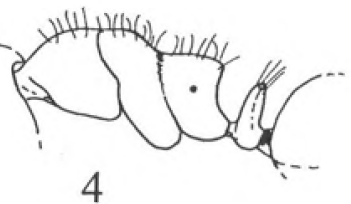

4

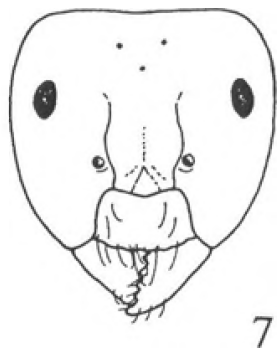

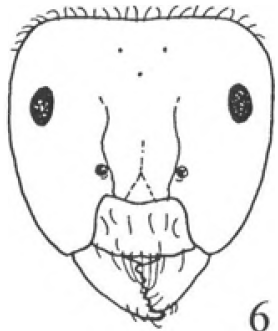

6

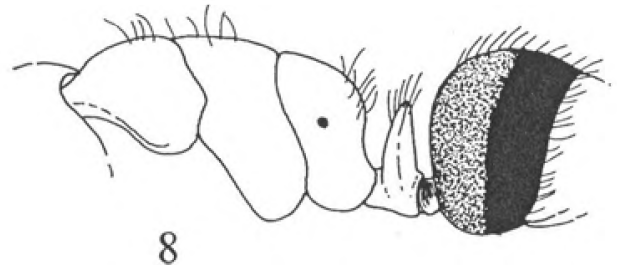

8

$2-5$

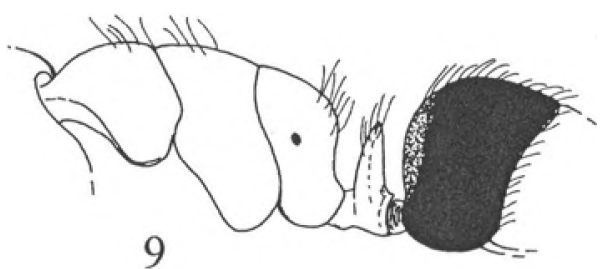

9

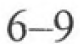

Figs 2-9. Details of structure of Camponotus species (workers): 2, $3-$ C. truncatus, $4-C$. piceus, $5-$ C. fallax, $6-C$. vagus, 7, 8 -C. ligniperda, 9 -C. herculeanus; 1 - head (of soldier; lateral view), 3, 4, 8, 9 - alitrunk, petiole and base of gaster, lateral view, 5 - lower part of head, dorsal view, 6,7-head, dorsal view. Scale bars: $1 \mathrm{~mm}$. 


\section{ACKNOWLEDGEMENTS}

The authors thank two referees, Vera Antonova and Joanna Pętal-Figielska, for reviewing and improving the manuscript. This paper has been prepared as part of a research project sponsored by the Ministry of Science and Higher Education, Warsaw - Grant No. N303 012 31/0604.

\section{REFERENCES}

AtANAssov N., Dlusskij G. M. 1992. Fauna na B'lgariya. 22. Hymenoptera, Formicidae. Izdatel'stvo na B'lgarskatu Akademiya na Naukite, Sofia, $310 \mathrm{pp}$.

BANASZAK J. 1977. Blonkówki (Hymenoptera) spotykane na dębach rogalińskich. Badania Fizjograficzne nad Polską Zachodnią 30: 109-115.

BERNARD F. 1967. Faune de l'Europe et du Bassin Méditerranéen. 3. Les fourmis (Hymenoptera, Formicidae) d'Europe occidentale et septentrionale 3(1968), Masson, Paris, $411 \mathrm{pp}$.

Borowiec M. L. 2007. Camponotus truncatus (Spinola, 1808) (Hymenoptera: Formicidae) - ant species new to Poland. Polish Journal of Entomology 76: 41-45.

CZECHOWSKI W., RADCHENKO A. \& CZECHOWSKA W. 2002. The ants (Hymenoptera, Formicidae) of Poland. Museum and Institute of Zoology PAS, Warszawa, $200 \mathrm{pp}$.

HÖLLDOBLER B. \& WILSON E. O. 1990. The ants. Harvard University Press, Cambridge Mass., xii +732 pp.

KRZYSZTOFIAK L. 1991. Mrówki rodzaju Camponotus Mayr (Hymenoptera, Formicidae) w Polsce, ich biologia i znaczenie gospodarcze. Prace Instytutu Badawczego Leśnictwa 716(1990): 101-118.

MATUSzKIEWICZ W. 1981. Przewodnik do oznaczania zbiorowisk roślinnych Polski. PWN, Warszawa, 298 pp.

PISARSKI B. 1961. Studien über die polnischen Arten der Gattung Camponotus Mayr (Hymenoptera, Formicidae). Annales Zoologici 9: 147-208.

RADCHENKO A. 1996. Opredelitelnaya tablica murav'ev roda Camponotus (Hymenoptera, Formicidae) Aziatskoj chasti Palearktiki. Zoologicheskij Zhurnal 75: 1195-1203.

RADCHENKO A. G. 1997. Obzor murav'ev podrodov Tanaemyrmex, Colobopsis, Myrmamblis, Myrmosericus, Orthonotomyrmex i Paramyrmamblis roda Camponotus (Hymenoptera, Formicidae) Aziatskoj chasti Palearktiki. Zoologicheskij Zhurnal 76: 806-815.

RADCHENKo A. 2007. Fauna Europaea: Formicidae. In: NoyES J. (ed.) Fauna Europaea: Hymenoptera: Apocrita. Fauna Europaea version 1.3, http://www.faunaeur.org.

RADCHENKO A., CZECHOWSKA W., CZECHOWSKI W., ANTONOVA V. \& STANKIEWICZ A. 2005. Myrmica lacustris Ruzsky (Hymenoptera: Formicidae), an ant species new for Poland. Fragmenta Faunistica 48: 167-174.

Radchenko A., Elmes G. W., Czechowska W., Stankiewicz A., Czechowski W. \& SiElezNIEW M. 2003. First records of Myrmica vandeli Bondroit and $M$. tulinae Elmes, Radchenko et Actaç (Hymenoptera: Formicidae) for Poland, with a key for the scabrinodis- and sabuleti-complexes. Fragmenta Faunistica 46: 47-57.

RADCHENKo A., StANKIEWICZ A. \& SIELEZnIEW M. 2004. First records of Myrmica salina Ruzsky (Hymenoptera: Formicidae) for Poland. Fragmenta Faunistica 47: 55-58.

SEIFERT B. 2007. Die Ameisen Mittel- und Nordeuropas. Lutra-Verlags- und Vertriebsgesellschaft, Görlitz, 368 pp.

STITZ H. 1939. Die Tierwelt Deutschlands und der angrenzenden Meersteile nach ihren Merkmalen und nach ihrer Lebensweise. 37. Hautflüger oder Hymenoptera. I: Ameisen oder Formicidae. G. Fischer, Jena, 428 pp.

\section{STRESZCZENIE}

[Drugie doniesienie o występowaniu Camponotus truncatus (Spinola) (Hymenoptera: Formicidae) w Polsce, z kluczem do oznaczania krajowych gatunków z rodzaju Camponotus Mayr]

Praca zawiera informację o wykryciu w Polsce drugiego stanowiska Camponotus (Colobopsis) truncatus (Spinola). Jest to medyterraneński gatunek dendrobiotyczny, oligotop jasnych, cieplych i suchych lasów liściastych, glównie dębowych. Robotnice C. truncatus znaleziono na pniach Dębów Rogalińskich w obrębie Rogalińskiego Parku Krajobrazowego (Nizina Wielkopolsko-Kujawska). Stanowisko to leży na północnej granicy zasięgu gatunku. Wcześniej w Polsce C. truncatus zostal stwierdzony na dębach w parku miejskim we Wroclawiu (Borowiec 2007). Spośród innych gatunków mrówek zebranych z pni starych dębów w Rogalinie na szczególną uwagę zasługuje - po raz pierwszy wykazany z Niziny WielkopolskoKujawskiej - Temnothorax corticalis (Schenck), malo znany dendrobiont euro-kaukaski, również oligotop jasnych i suchych lasów liściastych. Do pracy dolączony jest klucz do oznaczania krajowych gatunków z rodzaju Camponotus Mayr na podstawie robotnic. 